\title{
菱形角柱群管路内でのポケット部による流れの影響
}

\section{Effects of Wall Concavity on Flip-Flop Flows from Diamond-Shaped Cylinder Bundle}

\section{O正員 梅田眞三郎（福山大·工），飯嶋和明，新村浩一（三機工業） Wen-Jei Yang (Univ. of Michigan）}

\author{
Shinzaburo UMEDA, Fukuyama University, Fukuyama, Hiroshima, 729-0292 Japan \\ Kazuaki IIJIMA and Kouichi SHINMURA, Sanki Engineering Corp. Ltd. \\ Wen-Jei YANG, Univ. of Michigan
}

\begin{abstract}
The promotion of jet-stream diffusion may enhance the efficiency of mechanical performance in various industrial devices such as fluid machinery and combustion equipments. Both active and passive means were applied for the control of jet streams. Our previous studies disclosed that diamond-shaped cylinder bundles produce a self-excited oscillating jet-stream flow field having multiple uniform flow-rate groups. The present visualization work deals with effects of wall concavity on flip-flop flows in a diamond-shaped cylinder bundle. It is disclosed in the efflux jet streak-lines that characteristics of flip-flop flows are different in cases of the diamond-shaped cylinder bundle without and with wall concavity, respectively.
\end{abstract}

Key Words: Flip-flop flow, Diamond-shaped cylinder bundle with wall concavity, Flow visualization, Suction effect, Jet-stream diffusion

\section{1. まえがき}

流体機器や燃焼装置などの各種工業用機器においては, 噴 流拡散を促進させることにより, 機器性能の効率を向上させ る場合が見られる．既報(1)においては，交差流れを主流とす る菱形角柱群流路内にポケット部を設け, そこに吸引作用を 発現させ，縦渦を伴う自励振動噴流のフリップ・フロップ流 れの変化を調べてきたが, 本報告では, その結果の一部の紹 介とともに, ポケット部の形を変えた場合の追加実験結果を 述べる．紙面の制限から発表時に紹介する部分もある.

\section{2. 実験方法}

前年度までに菱形角柱群管路内でのポケット部の有無に よる管路内及びその流出噴流の流れの可視化実験を行って きたが, 今回はポケット部の形状を変化させた場合の流出噴 流について，PIV計測などによる可視化実験を行った．流 体として水と空気を用いた.

既に実験に用いてきたポケット部を有する菱形角柱群管 路図を図 1 に示す. その管路名として，以下ではWC L の記 号を用いる. 今回は，このポケット部のくり貫き部分の壁面 寄りの半分程度を埋める形（図 3 における斜線部）にし，ポ ケット部を浅くした場合の管路（記号：WC S）の流れの変 化も調べた．ポケット部が無い場合には，それらのくり貫き の部分のすべてが埋められた形, すなわちポケット無しの管 路（記号：NC）となっている.

流体として水と空気を用いた実験方法の詳細は既報 (1)に 示しているので,ここでは省略する.今回の実験結果写真に 関係する計測対象断面の概略図についてのみ図 2 に示した. すなわち, $\mathrm{y}=0$ で $\mathrm{x}=65$ と $75 \mathrm{~mm}$ の両点を中心として斜め方 向からの鉛直断面において, 水平方向に $60 \mathrm{~mm}$, 鉛直方向に $25 \mathrm{~mm}$ にわたった範囲の下にPIV 計測を行った.なおこの断 面については，計測時にトレーサとしての煙の流れ方向とカ メラ及びレーザー光の位置関係を考慮しなければならない ので, 図にも示しているが, その断面はy 方向にー $30^{\circ}$ 振っ た斜め方向になった.

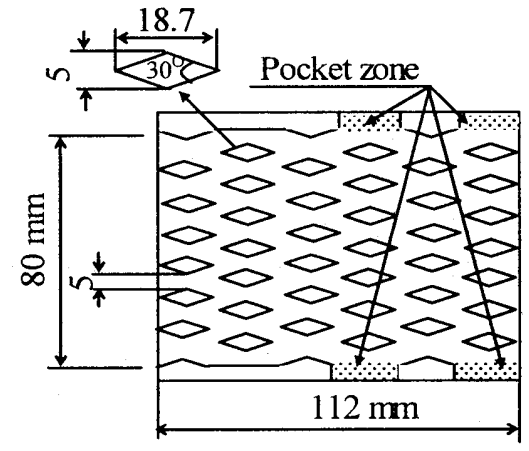

(i) Top view

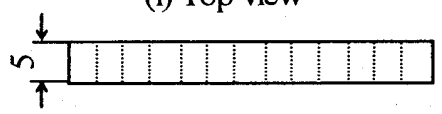

(ii) Side view

Fig. 1 Schematic of diamond-shaped cylinder bundle with wall concavity

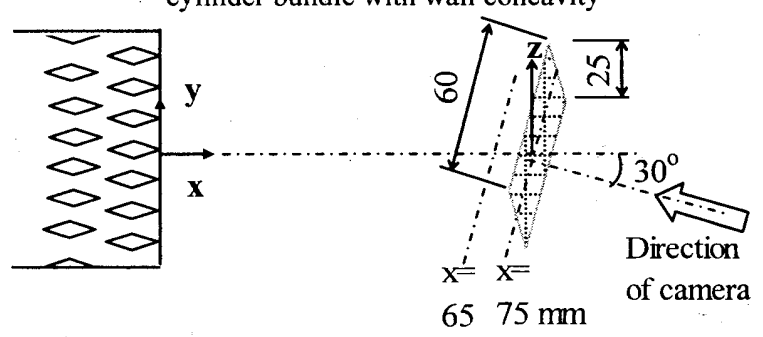

Fig. 2 Measuring sections from rear view in an oblique direction in PIV

\section{3. 実験結果と考察}

\section{1 ポケット部まわりの流れの可視化結果}

管路の上流側からハイポーラス・ポリマー粒子を投入し， デジタルカメラによる菱形角柱群管路上面からの流跡撮影 を行った．それらの結果の一例を図 3 に示した。この例につ いては，ポケット領域を浅くした管路であるWCSにおける 4 列目の左壁寄りの流れの可視化結果である. 3 列目の菱形 角柱の剥離領域に渦の形成が想像できる流跡がはっきりと 見られ，流れが左方向に向いたフリップ・フロップ流れの発 現が想像できる. ポケット部にかすかながら渦の旋回流跡も 確認できた。 


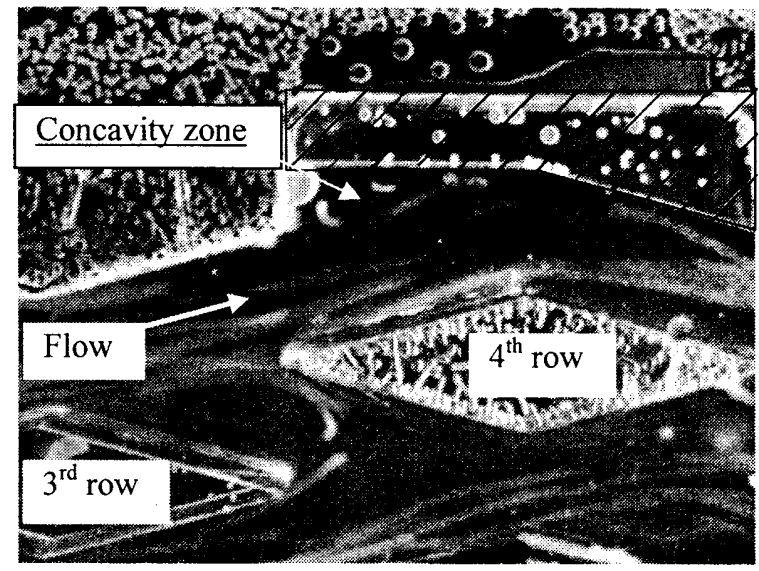

Fig. 3 Visualization of path lines around a left side wall $\left(t=t_{1}\right)$ from top view in the diamond-shaped cylinder bundle with wall concavity (WCS, $\operatorname{Re}_{\max }=7,700$ )

\section{2 流出喷流場での流れの変化}

下流側の斜め方向からの流出噴流の鉛直断面における流 れの可視化結果を図 4 (a) 〜 (c)に示す.これらの図は, 流出 噴流のある瞬間の画像であり, PIV でのトレーサである煙と 解析から得られたベクトルのそれぞれを同時に示している. 煙の流れ方向に直接カメラを据えることが難しく, 斜め方向 の鉛直断面における結果であるが，才べての連続画像からは ポケット部の有無に関係なく, 自励振動噴流のフリップ・フ ロップ流れの発現を確認することができている. 瞬時の画像 を示す(b)や(c)においても, ベクトルと煙の動きからフリッ プ・フロップ流れのような左右一の振動が示されているのが 理解できる. 特に, (a)や(c)の(i)に示される画像結果では, 中 央部の付近にはっきりとした分かれ目が見られ，フリップ・ フロップ流れの発現を証明していると考えられる.

最後に, ポケット部の有無による流出噴流の水平断面にお ける流れの違いを比較するために，P I V 計測を実施した. 計測領域は, $\mathrm{x}-\mathrm{y}$ 断面における $\mathrm{z}=0$ の水平中央断面での $\mathrm{y}=$ \pm 30 に囲われた $\mathrm{x}=10$ から $100 \mathrm{~mm} の$ 範囲で行った．流れの 横断方向の平均流速 V に関しての平均 $\mathrm{dV} / \mathrm{dy}$ の変化率を調べ た.レイノルズ数に対してのその変化を図 5 に示した. ポ ケット部が無い場合のN Cに対してのポケット部を有する 場合のWC L及びW C Sにおける流れの変化が異なってい ることを明らかにすることができた。

以上のように水空気における流れの可視化結果や PIV で の計測解析結果からも，ポケット部を有する場合の菱形角柱 群管路からの流出噴流場における流れの変化が大きく現れ ることを明らかにすることができた.

\section{4. 秸言会}

流体として水と空気を用いた可視化計測実験から菱形角 柱群管路内でのポケット部の有無及びポケット部の形状の 違いによる流れの変化を調べた. その結果, 菱形角柱群管路 内の左右の側壁側に設けたポケット部内には, 渦の旋回によ る吸引作用が発生し, その流出噴流流脈では, ポケット部の 形状によっても, フリップ・フロップ流れに変化が生じ, 左 右一の噴流の分散が大きく現れることが明らかとなった.

最後に本研究の一部は，科学研究費補助金 (No. 22560180) を受 けて実施したものであり、ここに記して感謝の意を表する。

\section{考文献}

(1)梅田他, 菱形角柱群管路内でのポケット部の有無による 流れの変化, 日本機械学会論文集 (B編), 75 巻 760 号, pp.2464-2471, 2009-12

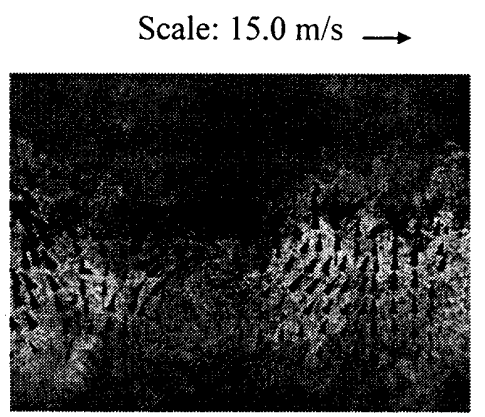

(a) Efflux plane of vertical section $(x=65)$ from the bundle with wall concavity (Time $\mathrm{t}=\mathrm{t}_{1}$ )

\section{Scale: $15.0 \mathrm{~m} / \mathrm{s} \rightarrow$}

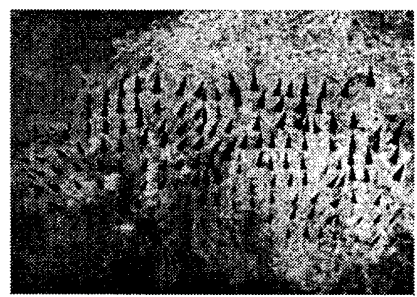

(i) $\mathrm{t}=\mathrm{t}_{2}$

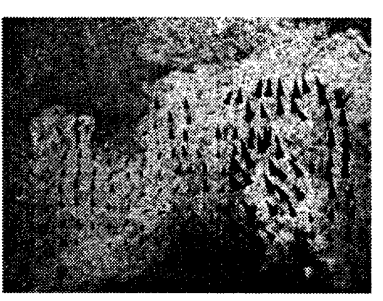

(ii) $t=t_{2}+2 d t$ (b) Efflux plane of vertical section $(x=75)$ from the bundle without wall concavity (Time $\mathrm{t}=\mathrm{t}_{2} \sim \mathrm{t}=\mathrm{t}_{2}+2 \mathrm{dt}$ )

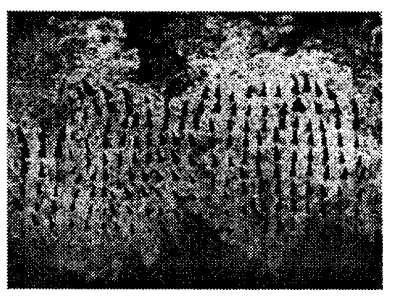

(i) $t=t_{3}$

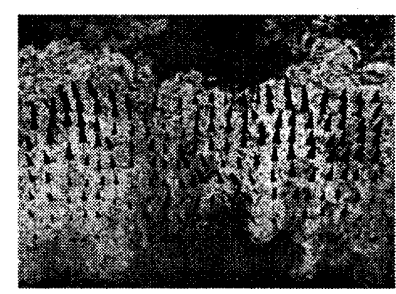

(ii) $\mathrm{t}=\mathrm{t}_{3}+\mathrm{dt}$ (c) Efflux plane of vertical section $(x=75)$ from the bundle with wall concavity (Time $t=t_{3} \sim t=t_{3}+d t$ )

Fig. 4 Flow patterns at certain instances in vertical section from an oblique direction $(\mathrm{dt}=67 / 1000 \mathrm{sec}$.)

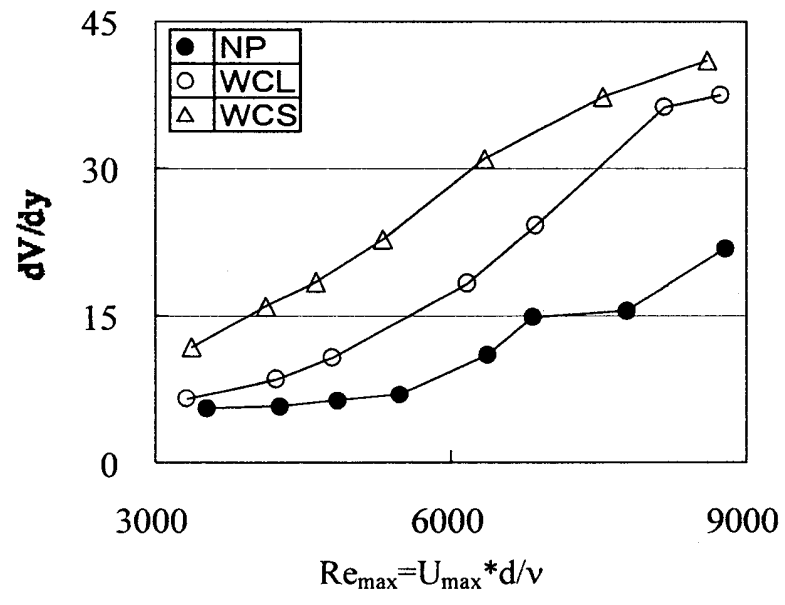

Fig. 5 Change of average $d V /$ dy versus $R e_{\max }$ 